\title{
A weather-based model for predicting early season inoculum build-up and spike infection by the wheat blast pathogen
}

\author{
José Maurício Cunha Fernandes ${ }^{1,2} \cdot$ Márcio Nicolau $^{1}$ • Willingthon Pavan ${ }^{2}$. \\ Carlos Amaral Hölbig ${ }^{2}$ - Maurício Karrei ${ }^{2}$ - Felipe de $\operatorname{Vargas}^{2}$. \\ Jorge Luis Boeira Bavaresco ${ }^{3} \cdot$ Alexandre Tagliari Lazzaretti $^{3} \cdot$ Rodrigo Y. Tsukahara ${ }^{4}$
}

Received: 16 February 2017 / Accepted: 24 May 2017 /Published online: 9 June 2017

(C) Sociedade Brasileira de Fitopatologia 2017

\begin{abstract}
Wheat blast, caused by the fungus Magnaporthe oryzae Triticum pathotype (MoT), is a serious disease capable of causing severe losses, especially during warm and humid weather conditions. Although the pathogen attacks all aboveground parts, infection of the wheat spikes is of major concern. In this work we developed and evaluated a prediction model based on the analysis of historical epidemics and weather series in the northern Paraná state, Brazil (Apucarana, Maringá and Londrina) and available epidemiological knowledge. The disease and weather datasets (hourly scale) examined encompassed the 2001-2012 period. A specific database management application (agroDb) helped to visualize and identify patterns in weather variables during two major outbreaks (2004 and 2009). Specifically, uncommonly humid and warm weather for most locations during a 60-day period preceding wheat heading during years of major outbreaks were considered key drivers of inoculum build up and airborne spores from regional inoculum sources in the surroundings. An inoculum potential (IP) and a spore cloud (SPOR) variable were estimated from models adapted from literature to predict inoculum build-up and availability. A day favoring infection (DFI) was conditioned to rules relating
\end{abstract}

Section Editor: Emerson M. Del Ponte

José Maurício Cunha Fernandes mauricio.fernandes@embrapa.br

Embrapa Trigo, Passo Fundo, RS 99001-970, Brazil

ICEG/UPF, CAMPUS I, Passo Fundo, RS 99001-970, Brazil

3 Instituto Federal Sul-Rio-grandense (IFSUL), Passo Fundo, RS 99001-970, Brazil

4 Fundação ABC, Castro, PR 84165-700, Brazil temperature and relative humidity for the day derived from the epidemic analysis. Successful daily infection (INF) during a DFI was conditioned to IP $>30$ and SPOR $>0.4$. To test the model, a wheat model simulated heading date for 10 planting dates, spaced 5 days apart, within a year, totaling 320 simulations. The model described well epidemic and non-epidemics conditions for the historical dataset, and was able to correctly predict epidemic (2015) and non-epidemic (2016) years not analyzed to build the model. An interactive risk-mapping tool that collects real-time weather data was developed for the target area to warn potential outbreaks. The system can be adapted to other regions where the disease is endemic or to asses the epidemic potential in regions where the disease is not present.

Keywords Magnaporthe oryzae · Triticum · Disease forecasting · Warning system

\section{Introduction}

Wheat blast disease is caused by the Triticum pathotype of Magnaporthe oryzae (MoT). The disease was first discovered in 1985 in Paraná State, Brazil (Igarashi et al. 1986). It further moved into other areas of Brazil and South America where erratic severe epidemics have been reported (Urashima et al. 2004; Kohli et al. 2011). The wheat blast pathogen might have evolved from South American M. oryzae isolates from other plant species, but its origin is unknown. Cruz and Valent (2017) provide an extensive and updated review of the importance, emergence and spread of wheat blast in South America and, more recently, in Bangladesh, Asia. The pathogen infects all above ground parts of the wheat plant, but spike infection is of greatest concern because severely bleached spikes do not produce grain. Severe epidemics occur during seasons with 
extended warm and high humidity (da Silva and Prabhu 2005; Alves and Fernandes 2006). Yield loss due to wheat blast can reach levels as high as $64 \%$ and may lead to total crop failure (Goulart et al. 2007). Fungicides are ineffective under high disease pressure and partially effective under moderate-to-low pressure. Despite intensive breeding efforts since the emergence of wheat blast in Brazil, no sources of durable resistance have been found (Cruz and Valent 2017).

Plant disease epidemics are, for their most part, well documented and properly represented by epidemiological models (Madden 2006). However, inoculum build-up and dispersal has received little attention, especially during the off-season, and are usually difficult to predict (Lucas 2006; Suffert et al. 2011). In regions where wheat blast is endemic, wheat crops are sown during the autumn, succeeding summer crops such as soybean and corn, and harvested in mid-late winter. However, perennial forage crops, such as signal grass, or annual crops, such as oats, which are known to be hosts of the wheat blast pathogen, are present in the landscape and thus provide a reservoir for the pathogen (Marangoni et al. 2013; Castroagudín et al. 2016). Persistent rainy and warm conditions may warrant pathogen survival during spring and summer seasons in the form of conidia and mycelia on seeds, wheat volunteers, plant debris, grass weeds and cultivated species. The widespread adoption of no-tillage practices in wheat growing regions in Brazil may contribute to extend the survival period.

Cardoso et al. (2008) developed a warning system for wheat blast based on temperature and spike wetness duration. The main limitation of infection-based models is the assumption that inoculum is always plenty during the susceptible period. In temperate wheat regions inoculum production is limited by freezing temperatures and so the inoculum may be available after the susceptible period, unless there is unusual favorable conditions for inoculum build-up early in the season (Farman et al. 2017). In contrast, under a tropical climate, moisture is more likely to be more limiting to inoculum production than temperature. Therefore, a wheat blast model that predicts both inoculum potential and favorability for infection would have a wider application.

Our hypothesis for the erratic occurrence of wheat blast epidemics in Brazil, which are limited to specific regions and seasons, is that a combination of weather events at both pre- and within-season, which affect inoculum build-up, spread and infection, need to occur for an outbreak to develop. The main objective of this study was to 1) analyze historical epidemics and seasonal weather to identify patterns associated with the epidemic and non-epidemic conditions, and 2) combine this information and available epidemiological knowledge for the disease in both wheat and rice to develop and evaluate a wheat blast model for predicting wheat blast outbreaks.

\section{Material and methods}

\section{Study area}

The study area encompassed the north and northwest regions of Paraná state, Brazil, where wheat blast is endemic and major outbreaks have been reported. The disease was never reported as a problem in southern subtropical regions of Paraná and Rio Grande do Sul, where most of the wheat production is concentrated in the country. Climate in the target region is classified as subtropical humid and mesothermic. Wheat flowering occurs during the winter months of July and August, which are usually drier, while wet conditions prevail from October to April (Reynolds et al. 2007). The region encompassed three municipalities in PR state: Londrina (Lat $23^{\circ} 18^{\prime} 37^{\prime \prime} \mathrm{S}$; Lon $51^{\circ} 09^{\prime} 46^{\prime \prime} \mathrm{W}$; Altitude: $585 \mathrm{~m}$ ), Maringá (Lat $23^{\circ}$ $25^{\prime} 31^{\prime \prime} \mathrm{S}$; Lon $51^{\circ} 56^{\prime} 19^{\prime \prime} \mathrm{W}$; Altitude: $596 \mathrm{~m}$ ) and Apucarana (Lat $23^{\circ} 33^{\prime} 03^{\prime \prime} \mathrm{S}$; Lon $51^{\circ} 27^{\prime} 39^{\prime \prime} \mathrm{W}$; Altitude: $820 \mathrm{~m}$ ).

\section{Historical wheat blast outbreaks}

A list of records of absence or presence (at various levels) of wheat blast outbreaks within the study area was made from various sources including reported surveys, research papers and consulting with wheat researchers and consultants. A wheat blast outbreak was assigned in a given location when its associated impact warranted reporting. During the 12-year period, wheat blast outbreaks varied from non-existing to highly severe (Table 1). During 2004 (Fig. 1a), wheat blast was reported in $51 \%$ and $47 \%$ of the interviews in the wheat production in the northern and the central regions of the state of Paraná (Ignaczk et al. 2005). In 2008 , wheat blast was reported in $37 \%$ and $62 \%$ of the interviews in the central and northern regions of the state of Paraná, respectively (Caierão et al. 2009). In 2009 (Fig. 1b), approximately 0.8 million hectares of wheat crop was affected which corresponded to approximately $1 / 3$ of the total wheat growing area in Brazil. Except for the outbreak of 2009, the reports did not provide specific dates for the onset of outbreaks.

\section{Weather data}

Weather data were obtained from the SIMEPAR (Technological Institute Simepar) automated weather station network. A group of weather stations were selected within in radius of approximately $100 \mathrm{~km}$ in the epidemic area encompassing Londrina, Maringá and Apucarana. Temperature $\left({ }^{\circ} \mathrm{C}\right)$, relative humidity $(\%)$, and rainfall $(\mathrm{mm} / \mathrm{h})$ were available at the hourly. Solar radiation $\left(\right.$ Watts $/ \mathrm{m}^{2}$ ) was obtained as daily values. 
Table 1 Reported wheat blast occurrence and score during 2001-2012 in Northern Paraná, Brazil and corresponding epidemic score

\begin{tabular}{llll}
\hline Year & $\begin{array}{l}\text { Wheat blast } \\
\text { occurrence }\end{array}$ & $\begin{array}{l}\text { Blast score } \\
\text { for wheat area } \\
\text { affected }\end{array}$ & Reference \\
\hline 2001 & Not Reported & - & To our best knowledge \\
2002 & Not reported & - & To our best knowledge \\
2003 & Not reported & - & Goulart et al. 2007 \\
2004 & Reported & Highly Severe & Ignaczk et al. 2005; \\
& & Goulart et al. 2007 \\
2005 & Reported & Moderate & Ignaczk et al. 2006 \\
2006 & Not reported & - & Ignaczk et al. 2007 \\
2007 & Not reported & - & De Mori et al. 2008 \\
2008 & Reported & Severe & Caierão et al. 2009. \\
2009 & Reported & Highly Severe & Caierão et al. 2010. \\
2010 & Not reported & - & Harger et al. 2011 \\
2011 & Reported & Low & Santana et al. 2013 \\
2012 & Reported & Low & De Mori et al. 2014 \\
\hline
\end{tabular}

1 none: Low: 10 to $20 \%$ of wheat area affected; moderate: 20 to $40 \%$ of wheat area affected; severe: $40-60 \%$ of wheat area affected; highly severe: 80 to $100 \%$ of wheat area affected

\section{Disease model components}

The model takes into account three major epidemic processes: 1) survival: it is hypothesized that inoculum surviving on known alternative hosts during the summer (January to March) needs to build-up extensively (massive conidia production) on alternative hosts prior or early in the season when humid and warm weather persists, which defines the inoculum potential; 2) dispersal: airborne conidia are short-lived and the density of a spore cloud declines exponentially over time, and 3 ) infection: starting at crop heading stage, viable conidia in a spore cloud infect wheat spikes when weather conditions are conducive. Follows details for each process.

\section{Inoculum potential (IP)}

This variable was proposed based on a rice blast model (Bregaglio and Donatelli 2015) to predict inoculum build-up during the pre-season. The rate of conidiophore formation is a function of hourly air temperature and relative humidity according to the equation:

$I P=\left\{\begin{array}{c}14.35-0.25^{*} T, \text { if } 15^{\circ} \mathrm{C}<T<27^{\circ} \mathrm{C} \text { and } R H \geq 93 \% \\ -8.5+0.59^{*} T, \text { if } 27^{\circ} \mathrm{C}<T<35^{\circ} \mathrm{C} \text { and } R H \geq 93 \% \\ 0, \text { otherwise }\end{array}\right.$

where $\mathrm{T}$ is hourly air temperature $\left({ }^{\circ} \mathrm{C}\right)$ and $\mathrm{RH}$ is relative humidity. A $93 \%$ threshold of relative humidity was used
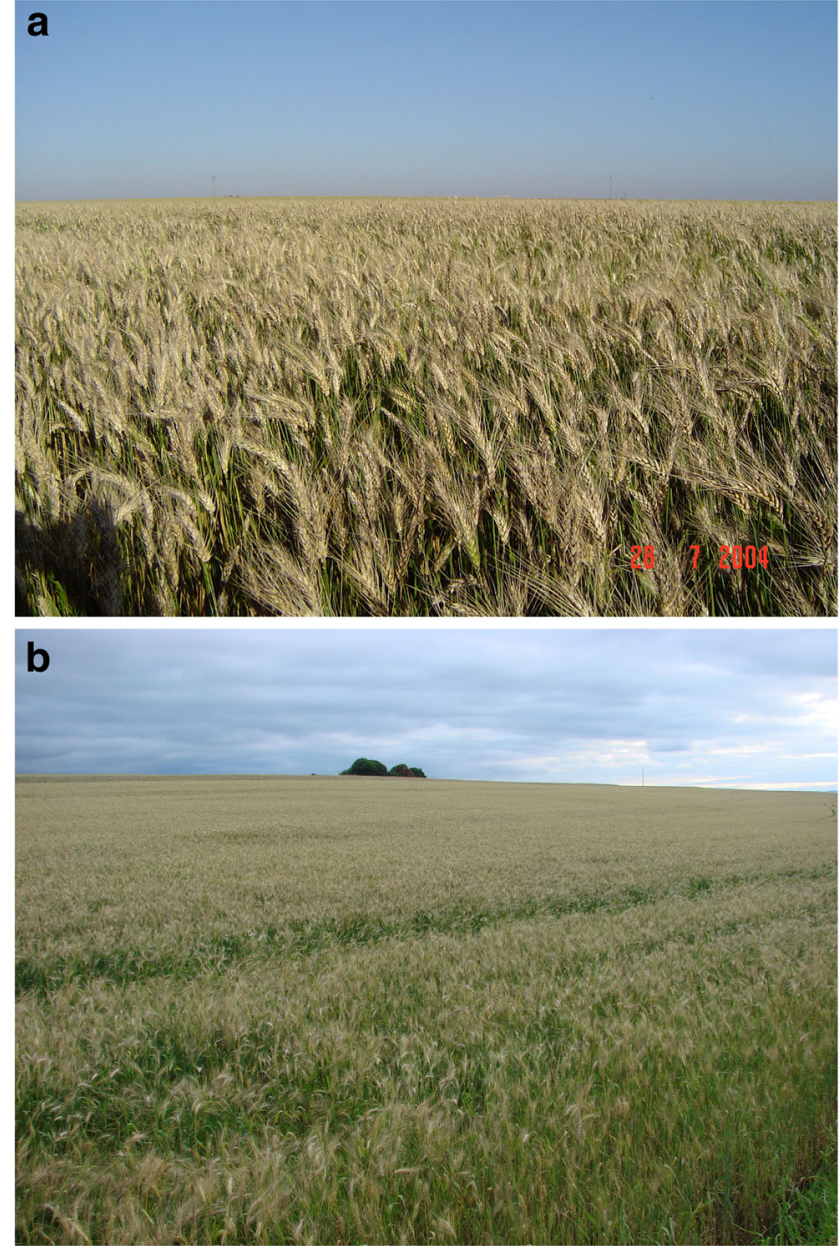

Fig. 1 Images of wheat fields affected with wheat blast in $27^{\text {th }}$ of July of 2004 and $24^{\text {th }}$ of August of 2009, in North of Paraná state in Brazil. (Images courtesy of P. L. Scheeren)

below which no thermal time is computed (Kim 2000). The reciprocal of daily IP, obtained as the sum of hourly IP, is then accumulated over the season. In the study area, IP is calculated from 60 days prior to the simulated heading stage, or around sowing, for a specific location. Inoculum source on non-wheat hosts was assumed to present uniform spatial pattern. It was also assumed that wheat blast pathogen inoculum during the summer months did not vary across years.

\section{Spore cloud (SPOR)}

We assumed that fungal spores that escape the host canopy are taken up by air currents and dilutes in the atmosphere by turbulent diffusion and wind shear during the transport (Deacon 2005). Inoculum survival in the airborne phase is strongly affected by environmental variables, including temperature, solar radiation, ultraviolet radiation, and relative humidity (Deacon 2005). It was further assumed that spore cloud density declines exponentially in the subsequent days after its formation. A given cohort of spores was assumed to have a 
half time of three days within a 7-day window. The R source code to estimate the spore cloud is available at https://github. com/felipedevargas/weather-based-model.

\section{Day favoring infection (DFI)}

Weather patterns during major outbreak years were analyzed to identify and select variables associated with spike infection. For the location of Londrina, we inspected weather from five to seven days prior to symptoms appearance during the 2004 and 2009 epidemics. We found that during 24 to 28 of July 2004 and 12 to 16 of August 2009, there was great similarity in daily solar radiation, daily temperature amplitude and daily relative humidity patterns (Fig. 2). In 2009, first symptoms were observed on August 19th. Based on these observations, a conditional 3-rule was empirically set to predict DFI: daily max $T>23{ }^{\circ} \mathrm{C}$, amplitude (daily max $\mathrm{T}$ - daily min T) $>13{ }^{\circ} \mathrm{C}$ and daily mean $\mathrm{RH}>70 \%$.

\section{Data exploration and visualization tool}

A web-based tool was developed to collect and summarize weather data for selected stations within the endemic region. The application consists of a graphical user interface for selecting location, year, wheat heading date, and values of reference lines in the plots. Based on the selection, a multipanel plot is dynamically created showing mean temperature, hours with temperature above a threshold, hours with $\mathrm{RH}$ greater than a threshold, total rainfall less than a threshold and the daily IP. A preliminary version of our model, which estimated only IP, was used to assess the risk of wheat blast in Kentucky, United States, based on historical weather (Farman et al. 2017). The application is freely available in a public repository (https://github.com/jlbavaresco/brusoneModel).

\section{Wheat simulation model}

The CSM-CROPSIM model included in DSSAT 4.6 (Decision Support System for Agrotechnology Transfer) was used to simulate growth and development of spring wheat (cultivar BRS Louro) under historical weather data and soil properties at different locations in the study area. This crop model has been evaluated and successfully used across sites throughout the world, including the modified version adapted to southern Brazil (Lazzaretti et al. 2015). The date of emergence of the first spikes in the tree locations and different years was obtained via simulation considering 10 sowing dates, spaced 5 days apart, during the entire sowing window season.

\section{Model implementation and simulations}

The model was coded in R statistical and programming language (R Core Team 2017) and uses Shiny (Chang et al. 2017) for visualizing model outputs (http://gpca.passofundo.ifsul. edu.br/agroweb). The model starts by the time of emergence of the first cohort of heads, which is predicted by the wheat model. Three variables are predicted: IP and SPOR are continuous variables and DFI is binary $(0,1)$. Figure 3 depicts model outputs presenting predicted and key meteorological variables. A fourth variable, an infection-conducive day (INF) derives from the conditional rule (IP $>=30$, SPOR $>=0.4$ and DFI $=1$ ). Seasonal INF (days) is then accumulated up to 30 days after heading date. The simulations were performed for the entire period (2001 to 2012) at the

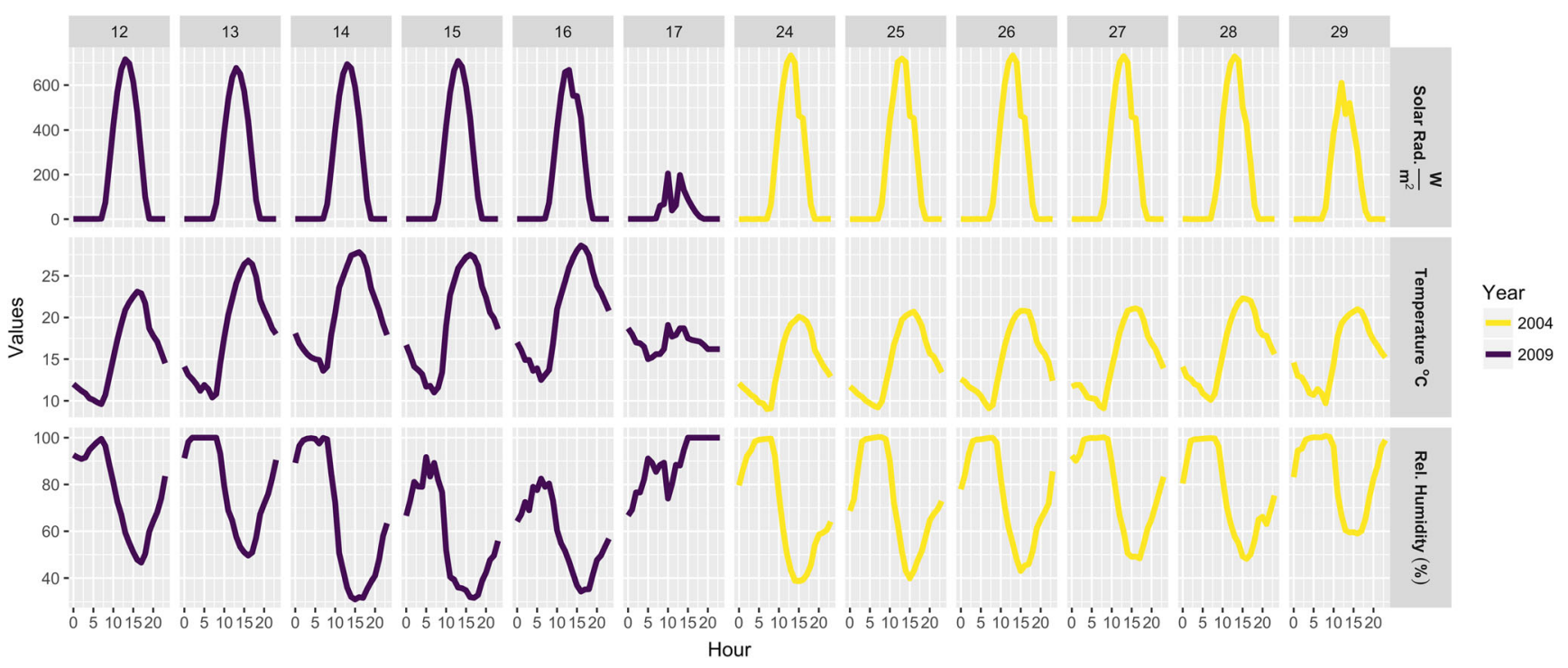

Fig. 2 Patterns of incoming solar radiation, temperature and relative humidity (during six consecutive days) at seven to three days prior to symptoms appearance in 2004 (August 12 to 17) and 2009 (August 24 to 29), in the locality of Londrina, PR, Brazil 


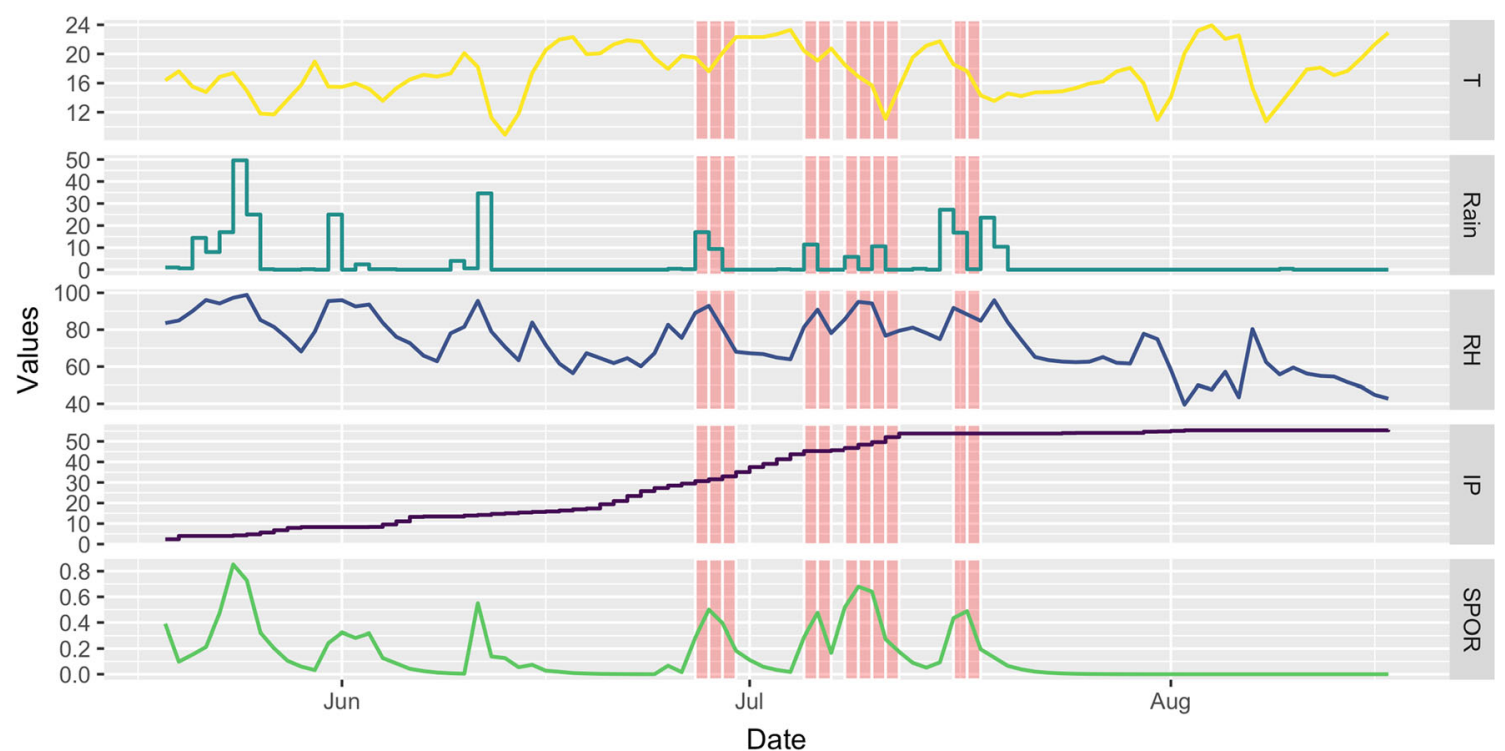

Fig. 3 Observed daily values of mean temperature (Celsius), rainfall $(\mathrm{mm})$, mean relative humidity (\%), estimated inoculum pressure (IP) and spore cloud size (SPOR). The vertical shaded areas represent the

three locations using the AgroDB tool (Lazzaretti et al. 2016). The R source code that estimates IP, SPOR and DFI is freely available (https://github.com/felipedevargas/weather-basedmodel).

\section{Model evaluation}

To evaluate the model we used field observations of wheat blast for the 2015 and 2016 seasons, representing epidemic and non-epidemic, respectively. During 2015, images of wheat fields showing typical blast symptoms on spikes, at different locations in the region, are available in the smartphone application Pic-a-Wheat Field (http:// picawheatfield.org/site/\#/map). In 2016, in the same region, not a single image of wheat fields showing typical blast symptoms on spikes was uploaded to the smartphone application. Extensive field surveys revealed total absence of wheat blast in the area (Dr André Cunha Rosa, personnel communication).

\section{Results}

\section{Model predictions}

Inspection of the weather data of Londrina from 2001 to 2012 during the corresponding wheat-growing season (April to August) showed larger variability in rainfall compared to temperature. In general July and August were the driest months. The highest average temperature was observed in April and the lowest in July.The IP values were more similar for Londrina and Apucarana, which were higher than in days conducive to infection (INF), in 2004, in the location of Londrina, PR, Brazil

Maringá. Highest values were found for 2004, 2005, 2008 and 2009. In the non-epidemic year of 2011, IP was below 20 in the three locations. There were 51 and 67 predicted DFIs in 2004 and 2009, respectively. In 2008, there were 32 DFI. In contrast, DFI ranged from 10 to 23 for the non-epidemic years. SPOR values during July and August varied considerably across years and locations (Fig. 4). Again, they were higher in Londrina and Apucarana than in Maringá. In the epidemic years of 2004, 2005, 2008 and 2009, SPOR reached values >11 Apucarana and Londrina. The DFI was more similar in Londrina and Apucarana, but lower in Maringá (Fig. 4). During the four epidemic years, DFI $>21$ were found in Apucarana and Londrina. The mean values of IP, SPOR and DFI were the lowest in Maringá.

\section{Model evaluation}

The comparison of the model outputs with a typical epidemic year (2015) and a non-epidemic (2016) showed that IP, SPOR and number of DFI varied across locations and years. IP was similar in both years. However, SPOR and DFI numbers were higher 2015 than 2016 (Fig. 5). For example, in Apucarana, 14 DFI were predicted, on average, for wheat crops heading between June 20 and July 7 in contrast to only two DFI for the same period in 2016 .

\section{Discussion}

In an emerging and erratic disease context, such as wheat blast, model development and evaluation is complicated by the lack of detailed field disease data. Previous efforts have 
Fig. 4 Mean estimates of inoculum pressure (IP), spore cloud size (SPOR) and number of days favoring infection (DFI) at three locations in the Northern part of the state of Paraná Brazil over ten simulations using sowing dates spaced at 5 days intervals from 2001 through 2012, respectively. The vertical the standard deviation segments on each bar represent

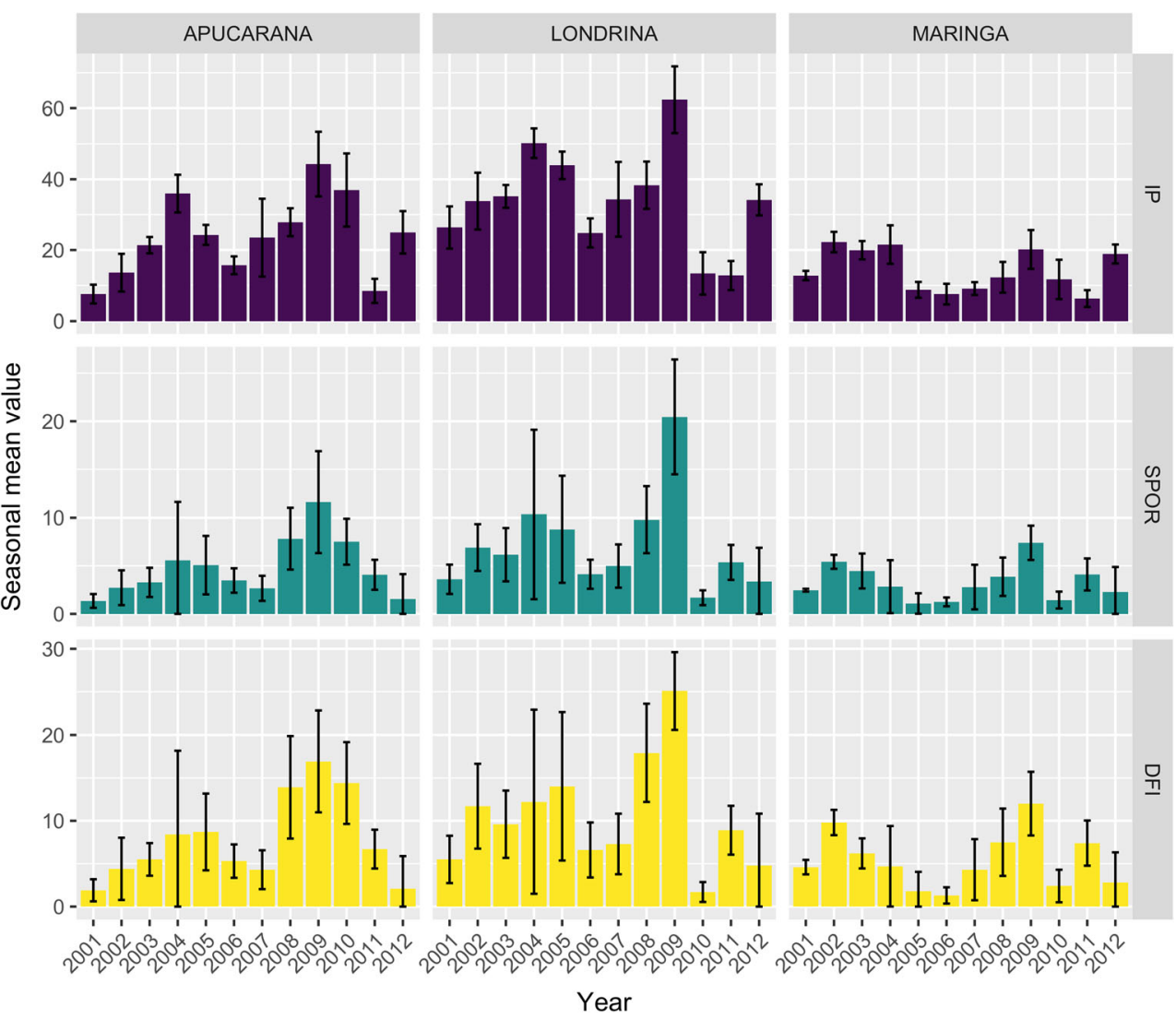

focused on specific processes of the disease cycle under a controlled environment (Alves and Fernandes 2006; Cardoso et al. 2008). To our knowledge, this is the first empirically derived wheat blast model that takes both inoculum potential and favorability for infection into account. Further refinements and evaluations will require long-term prospective data collection given the sporadic nature of wheat blast outbreaks.

We found that increased humidity and warm temperatures seemed relevant for predicting observed wheat blast outbreaks, which is consistent with knowledge of climate/wheat blast associations and provide further insight into wheat blast dynamics. The role of relative humidity and temperature in regulating the life cycle of $M$. oryzae has long been recognized (Calvero et al. 1996). Fungal spore deposition occurs by means of gravitational settling, turbulence or washed out of the air by rain. Sporulation of M. oryzae is reported to reach the maximum around early morning ( $\mathrm{Li}$ et al. 2013). The presence of dew is critical for infection because the wash out effect can result in the accumulation of spores on the rachis under prolonged duration of dew. In ryegrass, the relative humidity threshold for successful infection by $M$. oryzae was $\geq 92 \%$ at $28^{\circ} \mathrm{C}$ ( $\mathrm{Li}$ et al. 2014).

The ability to predict inoculum build-up during the months preceding spike emergence and grain filling stages of wheat based on weather patterns seems of great relevance in our model. The predicted IP was used to assess weather suitability for infection by wheat blast during spring 2011 in Kentucky, USA. Indeed, in that particular year, when the Kentucky wheat crop was heading in the area surrounding Princeton, the model predicted the risk of sufficient inoculum production and infection-conducive weather (Farman et al. 2017).

Tipically, temperatures during the fall and winter in northern Paraná are not limiting to $M$. oryzae survival as mycelium in living host tissue, host residue or in the seed. In contrast, populations of the pathogen are drastically reduced in temperate regions (Harmon and Latin 2005). In fact, wheat blast was not reported in southern Paraná, which may be due colder temperatures during the winter than in the north, which may limit earlyseason inoculum survival and dispersal.

During the major outbreaks in 2004 and 2009, days exhibiting high amounts of solar radiation were observed in a 10-day window before symptom appearance on spikes. Quality and intensity of ambient light condition triggers spore release when the mycelia experienced light followed by darkness (Lee et al. 2006). Profuse conidia of $M$. oryzae are formed when competent hyphae are exposed to aeration in combination with other factors such as humidity and light, which affects conidiation. Conversely, conidiation can be blocked by maintaining hyphae in submerged growth (Kim et al. 2012). 


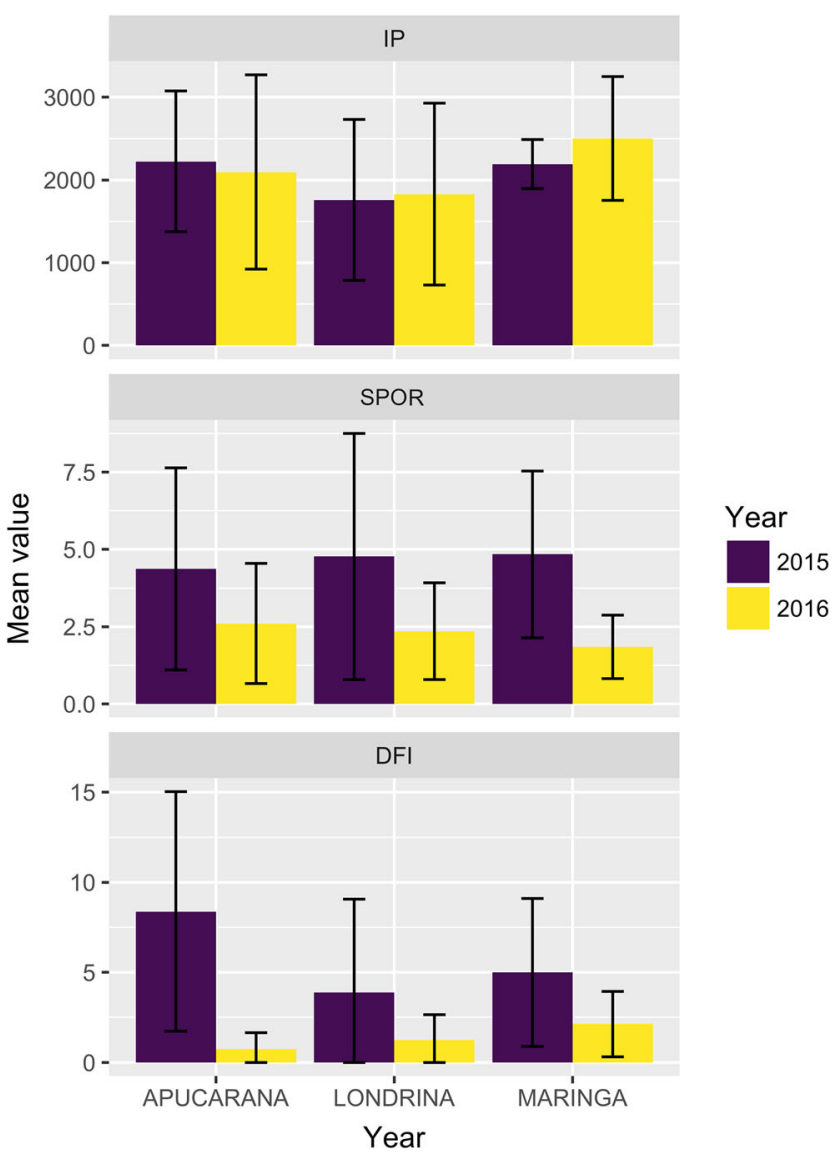

Fig. 5 Mean estimates of inoculum pressure (IP), spore cloud size (SPOR) and number of days favoring infection (DFI) for an epidemic (2015) and non-epidemic (2016) at three locations in the northern part of the state of Paraná Brazil over ten simulations using sowing dates spaced at 5-day interval. The vertical segments on each bar represent the standard deviation

Visual inspection of weather data during major outbreaks showed that a high frequency of rainy days and warm temperature occurred during heading and grain filling, succeeding wet fall and winter conditions which favored inoculum build-up. Conversely, drier weather during the fall and winter occurred during the non-outbreak years. These observations are consistent with fall and winter climatic patterns observed in the subtropical region where low precipitation is typically associated with above average temperatures. In addition, spatial distribution, diversity and phenology of susceptible hosts are important factors contributing to inoculum potential. Localized weather patterns can either enhance or inhibit growth and development of the wheat blast pathogen. At low elevations, especially nearby a body of water, wet conditions might contribute to $M$. oryzae growth and development favoring aerial dispersal to other areas. In the study area, large bodies of water exist, characterized by rivers or dams. Our model substantiate our present understanding of climate and wheat blast associations and provide further insight into those climate factors related to observed wheat blast outbreaks.
Further refinements are possible as more disease data is collected and evaluation is performed in other regions. The lack of data limited our ability to test the model, which was able to predict correctly epidemics for two contrasting years not used for model development (2015 and 2016). Improved and site-specific predictions are expected when taking into account the new quantitative knowledge on host range, sporulation and aerobiology. Continuing advances in information technology to develop user-friendly interactive portable system that allows user input of existing inoculum sources and site-specific estimates may facilitate risk communication. Additionally, expansion of the existing weather station network and use of remotely estimated or simulated weather data will expand spatial boundaries and refine the scale of the predictions. All these efforts may contribute to improve disease management. Fungicides when applied as a post-infection treatment are ineffective (da Silva and Prabhu 2005). However, it is possible that accurate predictions of outbreaks before flowering would improve fungicide effectiveness by correctly timing or avoiding unnecessary applications. Finally, it may be used to improve risk assessment studies to predict inoculum build-up and epidemic potential (Cruz et al. 2016) in other regions.

Acknowledgements The authors are thankful to the editor and to anonymous reviewers for their comments and suggestions. This work was partially supported by Agriculture and Food Research Initiative Competitive Grant no. 2013-68004-20378 from the United States Department of Agriculture National Institute of Food and Agriculture (USDA- NIFA) and by the CNPq Grant no. 444047/2014-0.

\section{References}

Alves KJP, Fernandes JMC (2006) Influência da temperatura e da umidade relativa do ar na esporulação de Magnaporthe grisea em trigo. Fitopatol Bras 31:579-584

Bregaglio S, Donatelli M (2015) A set of software components for the simulation of plant airborne diseases. Environ Model Softw 72:426444

Caierão E, Pasinato A, Harger N, Maurina AC, Pires JLF, Pimentel, MBM (2009) Uso de tecnologias em lavouras de trigo tecnicamente assistidas no Paraná - safra 2008. Embrapa Trigo, Documentos Online 111. Available at: www.cnpt.embrapa.br/biblio/do/p do111.htm

Caierão E, Pasinato A, Harger N, Maurina AC, Pires JLF, Pimentel, MBM (2010) Uso de tecnologias em lavouras de trigo no Paraná safra 2009. In: Pires JLF, Pasinato A, Caierão E, Tibola CS. Trigo: resultados de pesquisa - safra 2009. Embrapa Trigo, Documentos Online 96. Available at: http://ainfo.cnptia.embrapa.br/digital/ bitstream/item/128920/1/ID41962-2010-LVdocumentos96-p135154.pdf

Calvero SB Jr, Coakley SM, Teng PS (1996) Development of empirical forecasting models for rice blast based on weather factors. Plant Pathol 45:667-678

Cardoso CAA, Reis EM, Moreira EN (2008) Development of a warning system for wheat blast caused by Pyricularia grisea. Summa Phytopathol 34:216-221 
Castroagudín L, Moreira SI, Pereira DAS, Moreira SS, Brunner PC, Maciel JLN, Crous PW, McDonald BA, Alves E, Ceresini PC (2016) Pyricularia graminis-tritici, a new Pyricularia species causing wheat blast. Persoonia 37:199-216

Chang W, Cheng J, Allaire JJ, Xie Y, McPherson J (2017) Shiny: web application framework for R. Available at: https://CRAN.R-project. org/package= =shiny

Cruz, CD and Valent, B (2017) Wheat blast disease: danger on the move. Trop Plant Pathol. doi:10.1007/s40858-017-0159-z

Cruz, C. D., Magarey, R. D., Christie, D. N., Fowler, G. A., Fernandes, J. M., Bockus, W. W., Valent, B., and Stack, J. P. 2016. Climate suitability for Magnaporthe oryzae Triticum pathotype in the United States. Plant Dis. 100:1979-1987

da Silva GB, Prabhu AS (2005) Quantificação de Conídios de Pyricularia grisea no plantio direto e convencional de arroz de terras altas. Fitopatol Bras 30:569-573

De Mori C, Ignaczk JC, Maurina AC, Ferreira FA (2008) Uso de tecnologias nas lavouras de trigo tecnicamente assistidas do Estado do Paraná, Safra 2007. Available at: http://ainfo.cnptia.embrapa.br/ digital/bitstream/item/130215/1/ID43227-2008reuniaotrigo-CD192transf8.pdf

De Mori C, Harger N, Foloni JSS, Eichelberger L, Bassoi MC, Dossa AA, de Oliveira AB, Bodnar A, Fae GS, Tavares LCV, Cesa P (2014) Uso de tecnologias em lavouras de trigo tecnicamente assistidas no Paraná - safra 2012. Embrapa Trigo, Documentos Online 148. Available at: http://ainfo.cnptia.embrapa.br/digital/ bitstream/item/103757/1/2014-documentos-online148.pdf

Deacon, J (2005) Fungal spores, spore dormancy, and spore dispersal, in fungal biology, 4th edition, Blackwell doi:10.1002/9781118685068. $\operatorname{ch} 10$

Farman M, Peterson GL, Chen L, Starnes JH, Valent B, Bachi MP, Murdock L, Hershman DE, Pedley KF, Fernandes JMC, Bavaresco J (2017) The Lolium pathotype of Magnaporthe oryzae recovered from a single blasted wheat plant in the United States. Plant Dis 101:684-692

Framework for effects mediated by plant disease. Plant Pathol 60:15-30

Goulart ACP, Sousa PG, Urashima AS (2007) Danos em trigo causados pela infecção de Pyricularia grisea. Summa Phytopathol 33:358-363

Harger N, Bodnar A, Pasinato A, Caierao E, Pires JLF, Pimentel, MBM (2011) Uso de tecnologias em lavouras de trigo no Paraná, Safra 2010. In: $5^{\text {a }}$ Reunião da Comissão Brasileira de Pesquisa de Trigo e Triticale, Ata e resumos... Dourados: MS. Embrapa Agropecuária Oeste. Available at: http://www.alice.cnptia.embrapa.br/handle/doc/ 1024089

Harmon PF, Latin R (2005) Winter survival of the perennial ryegrass pathogen Magnaporthe Oryzae in north Central Indiana. Plant Dis 89:412-418

Igarashi S, Utiamada C, Igarashi L, Kazuma A, Lopes R (1986) Pyricularia em trigo. 1. Ocorrência de Pyricularia sp. no estado do Paraná. Fitopatol Bras 11:351

Ignaczk JC, Maurina AC, De Mori C \& Ferreira FA (2005) Uso de tecnologias em lavouras de trigo tecnicamente assistidas no Paraná - safra 2004. Embrapa Trigo, Documentos Online 51. Available at: http://www.cnpt.embrapa.br/biblio/do/p do51.htm

Ignaczk JC, Maurina AC, De Mori C, Ferreira FA (2006) Uso de tecnologias em lavouras de trigo tecnicamente assistidas no Paraná - safra 2005. Embrapa Trigo. Available at: http://www.infoteca. cnptia.embrapa.br/handle/doc/852105
Ignaczk JC, Maurina AC, De Mori C, Ferreira FA (2007). Uso de tecnologias em lavouras de trigo tecnicamente assistidas no Paraná - safra 2006. Embrapa Trigo, Documentos Online 86. Available at: http://www.cnpt.embrapa.br/biblio/do/p_do86.htm. Accessed on January 10, 2017

Kim KR (2000) Weather-driven models for rice leaf blast and their implementation to forecast disease development on the near real-time basis. PhD Thesis, Seoul National University, Suwon

Kim KS, Lee Y-H, Murillo J (2012) Gene expression profiling during conidiation in the rice blast pathogen Magnaporthe Oryzae. PLoS One 7:e43202

Kohli MM, Mehta YR, Guzman L, Viedma LD, Cubilla LE (2011) Pyricularia blast - a threat to wheat cultivation. Czech J Genet Plant Breed 47:S130-S134

Lazzaretti AT, Fernandes JMC, Pavan W (2015) Calibração do cropsimwheat para simulação do desenvolvimento e rendimento de grão de trigo no Sul do Brasil. Agrária 10:356-364

Lazzaretti AT, Fernandes JMC, Pavan W, Toebe J, Wiest R (2016) AgroDB - integration of database management systems with crop models. In: 8th international congress on environmental modelling and software, proceedings... Toulouse, France. iEMSs p. 194-201

Lee K, Singh P, Chung W-C, Ash J, Kim TS, Lisa H, Park S (2006) Light regulation of asexual development in the rice blast fungus, Magnaporthe Oryzae. Fungal Genet Biol 43:694-706

Li Y, Uddin W, Kaminski JE, Dufault NS (2013) Seasonal and daily patterns of Magnaporthe oryzae conidia availability in gray leaf spot-perennial ryegrass pathosystem. In: American Phytopathological society meeting, abstracts... Austin, TX, USA

Li Y, Uddin W, Kaminski JE (2014) Effects of relative humidity on infection, colonization and conidiation of Magnaporthe orzyae on perennial ryegrass. Plant Pathol 63:590-597

Lucas P (2006) Diseases caused by soil-borne pathogens. In: Cooke BM, Jones DG, Kaye B, eds. The epidemiology of plant diseases, 2nd ed. Dordrecht, the Netherlands: Springer, 373-86

Marangoni MS, Nunes MP, Fonseca N Jr, Mehta YR (2013) Pyricularia blast on white oats: a new threat to wheat cultivation. Trop Plant Pathol 38:198-202

R Core Team (2017) R: a language and environment for statistical computing. R foundation for statistical computing. Available at: https:// www.R-project.org/

Reynolds MP, Braun HJ, Pietragalla J, Ortiz R (2007) Challenges to international wheat breeding. Euphytica 157:281-285

Santana FM, Maciel JLN, Lau D, Seixas CDS, Bassoi MC, Goulart ACP, Sussel AAB, Schipanski CA, Montecelli TDN, Chagas JH, Guizeline J (2013) Eficiência de fungicidas para o controle da brusone do trigo: resultados dos ensaios cooperativos - safra 2011. Embrapa Trigo, Comunicado técnico Online 328. Available at: http://ainfo.cnptia. embrapa.br/digital/bitstream/item/103711/1/2013-comunicadotecnico-online328.pdf. Accessed on January 10, 2017

Suffert F, Sache I, Lannou C (2011) Early stages of septoria tritici blotch epidemics of winter wheat: build-up, overseasoning, and release of primary inoculum. Plant Pathol 60:166-177

Urashima A, Martins T, Bueno C, Favaro D, Arruda M, Mehta Y (2004) Triticale and barley: new hosts of Magnaporthe grisea in São Paulo, Brazil - relationship with blast of rice and wheat. In: Kawasaki S (ed) Rice blast: interaction with rice and control. Netherlands. Springer, Dordrecht, pp 251-260 